DOI: $10.19195 / 0137-1134.109 .20$

\author{
MINDAUGAS MAKSIMAITIS \\ Uniwersytet im. Michała Römera w Wilnie
}

\title{
MICHAŁ RÖMER W WILNIE 1940 ROKU
}

\section{WSTĘP}

Można rzec, że dorobek sześćdziesięciopięcioletniego życia Michała Römera jest na tyle bogaty, że można by nim obdzielić kilka życiorysów. Karty jego biografii dostarczają wiele materiałów do przemyśleń, mogą posłużyć jako swoista szkoła życia państwowego, społecznego i osobistego.

Zainteresowanie tym ponadprzeciętnie zasłużonym dla państwa litewskiego człowiekiem, powszechnie znanym prawnikiem, cieszącym się autorytetem aktywnym działaczem państwowym i społecznym, naukowcem wielu dziedzin, pamiętnym pedagogiem-profesorem, świetnym politycznym analitykiem, pierwszym historykiem litewskiego odrodzenia narodowego, oddanym walczącym publicystą, który odszedł 70 lat temu, nie zanika nie tylko w jego ojczyźnie. Szczególnym zainteresowaniem cieszy się jego działalność z lat młodzieńczych, poświęcona podyktowanym przez ówczesne realia bolesnym poszukiwaniom drogi dla Litwy, wymagającym samozaparcia, odwagi osobistej, poświęcenia i tytanicznych starań, ale w konkluzji zakończonych raczej rozczarowaniem niż radością. Nie mniejszym zainteresowaniem cieszy się druga strona życia Römera — praca dla odnajdującej siebie i krzepnącej Litwy, która dostarczyła sporo satysfakcji w postaci ewidentnych efektów zainwestowanych starań, które były jak dar od losu w zamian za niepowodzenia bliskiej przeszłości. Niezwykła energia, szeroka erudycja, niezachwiane przekonania demokratyczne i tolerancja, głębokie zrozumienie idei obywatelskiej oraz inne pozytywne cechy charakteru pozwoliły mu naprawdę wiele dokonać dla dobra ojczystego kraju.

Zauważalnie mniejsze zainteresowanie badaczy budzi ostatni etap życia Römera, który przypadł na czas II wojny światowej wraz ze zmieniającymi się okupacjami, kiedy to wycofał się z działalności państwowej, a wkrótce i społecznej. Tych pięć lat z okresu wielkich załamań w historii ojczyzny było najdramatyczniejszym etapem życia Römera, który nie zaakceptował żadnego okupanta. W realiach, w których nastąpywały nieprzewidywalne zmiany sytuacji społecz- 
nych, doszło do zjawiska dławienia wszelkiej aktywności inteligenckiej, w tym akademickiej. Podobnie jak wiele innych szanowanych osobistości, Römer był zmuszony do zamknięcia się w sobie oraz kręgu najbliższych ludzi i z tego powodu stał się mniej zauważalny.

Uwadze czytelnika proponuję artykuł poświęcony jednemu, szczególnemu rokowi kalendarzowemu z tego okresu, który zwrócił mu Wilno jego młodości, w którym jak niegdyś musiał zmierzyć się z odwiecznym dla niego problemem stosunków polsko-litewskich, a wkrótce doświadczyć niosącej zgoła inne problemy sowieckiej okupacji.

\section{EKSPERT W DZIEDZINIE PROBLEMÓW WILEŃSZCZYZNY}

Rok 1939 zapisał się w historii wieloma ważnymi i przełomowymi zmianami dla wielu państw i narodów. Wniósł też istotne korekty w życiu osobistym Römera. Koniec piastowania przez dwie trzyletnie kadencje stanowiska rektora Uniwersytetu im. Witolda Wielkiego, powrotne przyłączenie do Litwy Wilna - miasta młodości Römera - oraz przeprowadzka do niego z Kowna, które zdążyło stać się krajowym centrum politycznym, nie pozostały bez wpływu na życie profesora o szacownym wieku.

„Cieszy mnie odzyskanie naszej starej stolicy — przyznał podówczas Römer. - Więzi tworzonych wiekami nie da się zerwać za jednym razem. Płakałem, gdy słuchałem radiowej relacji z wkroczenia naszych wojsk do Wilna"1. To nie tylko poruszało uczucia, lecz także stwarzało duże trudności. Wrażliwie przeżywając wydarzenia, analizując ich nieodzowny wpływ na życie państwa i narodu, dzielił się ze społeczeństwem swoimi wizjami i prognozami dotyczącymi Wileńszczyzny.

Analizując z pozycji prawa międzynarodowego oraz idei neutralności Litwy przejęcie Wilna od Związku Sowieckiego, na podstawie Konstytucji Litwy z 1938 r. określającej granice terytorialne państwa oraz na podstawie umowy z 12 lipca 1920 r. pomiędzy Litwą a Moskwą określającej południowo-wschodnie granice, stwierdził on, że względem Polski Litwa była i pozostała neutralna ${ }^{2}$. Ten fakt historyczny, jako zawodowy prawnik, ocenił ,jako [powrót — przyp. red.] do swego konstytucyjnego terytorium i stolicy, która dotąd faktycznie była władana przez Polskę [...] i która wypadłszy z polskich rąk, została odzyskana przez Litwę nie siłą, nie agresją wobec będącej w stanie wojny Polski, ale tytułem restytucji swojego prawa, bez przemocy i bez czynnego konfliktu z Polską"3.

\footnotetext{
M. Römerio 19391105 laiškas J. Petruliui. Jok. Petrulio nuosavybè.

2 M. Römer, Vilnius ir tarptautine teise, ,Naujoji Romuva” 1939, nr 48, s. 394-397.

3 M. Römer, Universiteto problema ir Stepono Batoro universitetas, „Židinys” 1939, nr 12,
} s. 675 . 
Równocześnie rozczarowanie przyniosła zawarta 10 października 1939 r. umowa pomiędzy Litwą a Związkiem Radzieckim, w myśl której do Litwy wróciła tylko część terytorium uznanego przez Moskwę umową z 1920 r. i zamieszkałego przez Litwinów. Co więcej, Römer dostrzegał źródło nowych problemów i zagrożeń w zobowiązaniu do przyjęcia baz obcych wojsk na terytorium Litwy — ,za zasłoną odzyskanego Wilna kryją się radzieckie załogi, [...] przyczułki do zagarnięcia Litwy"4.

Euforię thumiło też pojmowanie złożonych problemów wewnętrznych w związku z powrotem Wileńszczyzny do Litwy.

Römer brał udział w rządowych rozważaniach na temat przejściowego statusu Wilna i Wileńszczyzny w składzie państwa litewskiego. Wypowiedział się tu przeciwko natychmiastowemu wprowadzeniu obowiązywania na Wileńszczyźnie ustawodawstwa litewskiego, optował z kolei za bardziej elastycznym projektem administracyjnym, uwzględniającym lokalne uwarunkowania. Drogą kompromisu zdecydowano o stosowaniu do stosunków prawa prywatnego tych ustaw, które owe stosunki ukształtowały ${ }^{5}$, tj. głównie ustaw polskich.

Römer z charakterystyczną dla siebie skrupulatnością i spostrzegawczością zaczął analizować też inne problemy wynikłe z odzyskania Wileńszczyzny. Starał się rozwiać wątpliwości części społeczeństwa odnośnie do przeniesienia stolicy z Kowna, które w ciągu ostatniego dwudziestolecia znacznie wyrosło i się zmodernizowało, do Wilna, będącego prowincjonalnym miastem Polski. Należało też przekonać niechętną, zasiedziałą w Kownie biurokrację do przeniesienia się do miasta, które zdawało się ponure i obce. Römer bezwarunkowo trzymał się pozycji, że Litwa kierując się ciągłością swojej państwowości, powinna za swoją stolicę historyczną uznawać Wilno 6 .

Osobny artykuł poświęcił aktualnej podówczas kwestii obywatelstwa mieszkańców Wileńszczyzny ${ }^{7}$.

Patrząc na perspektywy życia akademickiego, będące również aktualnym problemem, Römer nie widział możliwości utrzymania polskiego Uniwersytetu im. Stefana Batorego, przy czym nie uznawał tego za przejaw polityki antypolskiej, tylko za skutek obiektywnej rzeczywistości ${ }^{8}$. Uważał, że procesu reorganizacji polskiego uniwersytetu należy dokonać jak najbardziej humanitarnie, możliwie neutralizując naturalne w takich okolicznościach poczucie straty części mieszkańców.

4 J. Sawicki, Mykolas Römeris ir buvusios Lietuvos Didžiosios Kunigaikštystès žemiu tautinès problemos, „Lietuvių atgimimo istorijos studijos” 15, Vilnius 1999, s. 66.

5 Vilniaus miesto ir jo srities tvarkymo ìvedamasis istatymas, „Vyriausybès žinios” 1939, nr 671 (4946); M. Römer, Dziennik, t. 37, Vilniaus universiteto bibliotekos Rankraščiu skyrius (dalej: VUB RS), zesp. 75-13, karta 151.

${ }^{6}$ Nebaigtas M. Römerio straipsnis, Lietuvos mokslų akademijos Vrublevskių bibliotekos Rankraščiu skyrius (dalej: LMAB RS), zesp. 138-2265, karta 1.

${ }^{7}$ M. Römer, Kelios pastabos pilietybès konstatavimo reikalu Vilniaus srity, „Teisë” 1940, nr 51.

8 M. Römer, Universiteto problema ..., s. 679. 
W związku z problemem losów i współpracy Uniwersytetu im. Witolda Wielkiego w Kownie i Uniwersytetu im. Stefana Batorego w Wilnie Römer w składzie specjalnej komisji udał się do Wilna, aby zapoznać się ze stanem wydziału prawa Uniwersytetu im. Stefana Batorego ${ }^{9}$. Był stronnikiem idei istnienia na Litwie dwóch uniwersytetów - w Kownie i Wilnie ${ }^{10}$. Brał udział w przygotowaniu projektu nowej ,ustawy o uniwersytetach"11. Przyjęta przez Sejm i ogłoszona 16 grudnia $1939 \mathrm{r}^{12}$ ustawa przywróciła Uniwersytet Wileński oraz nakazała rządowi przeniesienie do niego części wydziałów z Kowna. Na podstawie ustawy Rada Ministrów zdecydowała o utworzeniu na Uniwesytecie Wileńskim wydziałów Prawa i Nauk Humanistycznych poprzez ich przeniesienie wraz ze studentami i profesorami z Uniwersytetu im. Witolda Wielkiego.

Przeniesienie starszej kadry naukowej od 1 stycznia 1940 r. z Kowna do Wilna było sformalizowane przez specjalny akt prezydencki z dnia 18 stycznia $^{13}$, który dotyczył 13 członków kadry naukowej Wydziału Prawa, w tym Römera ${ }^{14}$.

\section{W WILNIE: OSTATNIE PÓŁROCZE NIEPODLEGŁOŚCI LITWY}

Naturalne trudności związane z przeprowadzką nie wzbudzały entuzjazmu wśrod profesorów. W odróżnieniu od nich Römer entuzjastycznie przyjął fakt oddelegowania do Wilna i był jednym z nielicznych, którzy dla dobra państwa ochoczo zgodzili się na zmianę miejsca zamieszkania i pracy ${ }^{15}$. Nie posiadając w Kownie nieruchomości, nie był materialnie przywiązany do tego miasta. Żałował tylko dobrego wynajmowanego mieszkania i nie spodziewał się w Wilnie niczego lepszego ${ }^{16}$. Przyjechał, jak sam twierdził, 1 stycznia 1940 r. ${ }^{17}$ i zamieszkał na ulicy Bonifratrów w domu o ówczesnym numerze $2^{18}$. Adres ten pozostał jego

9 Vytauto Didžiojo universiteto Teisiu f-to 19391026 tarybos poseddžio protokolas, Lietuvos centrinis valstybès archyvas (dalej: LCVA), zesp. 631, opis 1, teczka 225, karta 311; A. Augustaitis, Taip prasidejo nauja VU era, „Universitas Vilnensis” 1940, $\mathrm{nr} 4$.

10 Nebaigtas M. Römerio straipsnis, LMAB RS, zesp. 138-2282, karta 1.

11 I. Šenavičienè, A. Šenavičius, Vytauto Didžiojo universiteto struktūra 1922-1950 metais: geneze, raidos metmenys, Vytauto Didžiojo universitetas. Mokslas ir visuomenė 1922-2002, Kaunas 2002, s. 97; P. Žostautaite, VDU ir Vilniaus universiteto atkūrimas 1939-1940 metais, Vytauto Didžiojo universiteto ir Lietuvių katalikų mokslo akademijos 70-metis, Kaunas 1993, s. 44.

12 Universitetu istatymas, „Vyriausybès žinios” 1939, nr 683-5078.

13 Respublikos prezidento 19400118 aktas, LCVA, zesp. 631, opis 3, teczka 620, karta 1.

14 Vilniaus universiteto rektoriaus 19400221 akto nuorašas, LCVA, zesp. R-856, opis 2, teczka 734, karta 19.

15 M. Römer, Dziennik, t. 37, karta 172.

16 Ibidem, karta 175.

17 Prof. Mykolo Römerio autobiografija, „Lietuvių atgimimo istorijos studijos”, t. 13, Vilnius 1996, s. 238.

18 Obecnie jest to ulica Liejyklos/L. Stuokos-Gucevičiaus, nr 13/10. Na tym budynku w 2005 r. odsłonięto tablicę pamiątkową z okazji 125 . rocznicy urodzin M. Römera. 
oficjalnym miejscem zamieszkania aż do śmierci. Pocieszał siebie tym, że stratę kowieńskich wygód rekompensuje piękna okolica nowego miejsca zamieszkania w sercu miasta - plac katedralny, piękne ogrody nad Wilenką (dzisiaj — Sereikiškiu parkas), wzgórze Giedymina wraz z zamkiem, widok z balkonu na aż siedem kościołów, a w parku Pałacu Reprezentacyjnego (dzisiaj — Prezydentura) wieczorami słychać śpiew słowików... ${ }^{19}$

Niemniej pierwsze wrażenia Römera nie były przyjemne. Odczuł, że „w Wilnie nie jest spokojnie, [...] wiele nieszczęść, ogromny wstrząs, nastrój mieszkańców coraz bardziej mętny" 20 .

O osobistych perypetiach związanych z przeprowadzką ukochanej, acz późno założonej rodziny i narodzinami drugiej córki, 26 stycznia 1940 r., wspominać tu nie wypada.

Na pierwszym posiedzeniu rady uniwersytetu wybierany był rektor. Wśród kandydatów był też Römer. Zdaniem M. Biržiški, który został wówczas rektorem, doświadczenie Römera na tym stanowisku nie wygrało ze względów politycznych — uznano, że człowiek uważający siebie za Polaka (choćby i Polaka Litwy, jak sam siebie $\mathrm{zwa}^{21}{ }^{21}$ ) nie jest odpowiednim kandydatem na rektora uniwersytetu, który właśnie stawał się litewski, zwłaszcza że w świadomości litewskiej dominował pogląd, że uniwersytet początkowo łaciński, później polski, zawsze był „obcy dla ducha narodu litewskiego", a zatem nadszedł czas zmienić tę niesprawiedliwość 22 .

Römerowi, jak dotychczas, pozostawiono Katedrę Prawa Państwowego. Studentom prawnikom wykładał prawo państwowe, a studiującym na Wydziale Prawa ekonomistom - prawo państwowe i administracyjne ${ }^{23}$. Wielkie wrażenie na słuchaczach sprawił opisany przez niego szczegółowo w dzienniku pierwszy wykład z 30 stycznia $1940 \mathrm{r}$.

Poza zwykłą pracą pedagogiczną Senat Uniwersytetu powierzył mu ważne w ówczesnych warunkach zadanie poza wydziałem - miał oficjalnie opiekować się domami studenckimi na ulicy Turzej. Były one przeznaczone dla studentów przeniesionych z Kowna oraz częściowo dla kadry naukowej, ale w rzeczywistości wciąż mieszkało tam wielu byłych studentów Uniwersytetu im. Stefana Batorego, którzy w realiach wojny i okupacji Polski stali się uchodźcami, a których status nie pozwalał na ich eksmitowanie. Opiekun domów studenckich miał ich reprezentować przed organami uniwersytetu, rozpatrywać zażalenia ich mieszkańców i pracowników itd. ${ }^{24}$
19 M. Römer, Dziennik, t. 37, karta 257.
${ }^{20}$ M. Römerio 19400112 laiškas M. Urbšienei-Mašiotaitei, Nacionalinès M. Mažvydo bibli- otekos Rankraščių skyrius (dalej: NMB RS), zesp. 14-613, karta 2.
21 M. Biržiška, Prof. Mykolas Römeris, Tremties metai, Tübingen 1947, s. 554.
22 Vilniaus universitetui darba pradedant, „Lietuvos aidas” 1940, $\mathrm{nr} 23$.
23 Vilniaus universiteto 1940 m. pavasario semestro paskaitu tvarkaraščiai ir taisyklès, Vilnius 1940, s. 20, 23-25.

24 Ibidem, s. 36. 
Po zainicjowaniu przez kadrę uniwersytetu akcji mającej zapoznać społeczność Wilna z podstawowymi realiami państwowymi Römer odczytał w języku polskim publiczny wykład Organizacja władzy politycznej wedtug Konstytucji Litwy ${ }^{25}$.

Przeprowadzka Römera do Wilna ograniczyła wciąż rezydującemu w Kownie rządowi możliwość zwracania się do niego w wypadku większych wątpliwości wymagających głębokiej wiedzy konstytucyjnej. Za to w Wilnie pozostał społecznikiem, takim jakim był w ciągu całego życia. Nie ograniczając się do funkcji przewodniczącego Stowarzyszenia Prawników Litwy ${ }^{26}$, poświęcił się stosunkom litewsko-polskim, stając się swoistym ogniwem łączącym litewską i polską część społeczności Wileńszczyzny ${ }^{27}$.

Był to czas, który niejako przeniósł Römera do czasów młodości, pozwalając mu na ponowne próby realizacji swojego powołania, polegającego na szukaniu wspólnych punktów dla obu kultur, na staraniach zbliżenia ich do siebie. Z tym że wtedy — na przełomie XIX i XX w. — były to równoprawne narody byłego Wielkiego Księstwa Litewskiego, a w roku 1940 Litwini reprezentowali naród rządzący, a Polacy byli mniejszością narodową ${ }^{28}$.

Wiele czasu poświęcał zagadnieniom tych stosunków ${ }^{29}$, sprzeciwiając się jakiemukolwiek przymusowi, który w jego przekonaniu mógł przynieść wiele złego państwu litewskiemu. Nie miał wątpliwości, że dyskurs z wieloma mieszkańcami tych terenów powinien być prowadzony z odpowiednim kulturowym taktem. Chcąc mieć swój udział w rozwiązaniu, jak to określił — „ogromnej odpowiedzialności i niezwykle ciężkiego problemu"30, ruszył z inicjatywą zrzeszenia w klubie dyskusyjnym znaczniejszych działaczy społecznościowych Wileńszczyzny, Polaków i Litwinów, rozumiejących ,sprawę wspótistnienia tych dwóch społeczności we Wschodniej Litwie”, chcących „poznać swoją psychikę i rozumowanie", wspólnymi staraniami tolerancyjnie rozwiązywać trudne litewsko-polskie problemy, rozwijać dialog i szukać punktów zgody ${ }^{31}$.

Pierwsze spotkanie tej grupy miało miejsce 12 lutego 1940 r. w domu Römera. Tego dnia, a także później, rozmowy były prowadzone otwarcie, a duże znaczenie miał autorytet Römera i szacunek, jakim darzyli go Polacy ${ }^{32}$. „Wygląda na to — cieszył się Römer — że ta sprawa nieźle się rozwija"33.

25 P. Žostautaitè, op. cit., s. 49.

26 M. Römer, Dziennik, t. 37, karta 233.

27 R. Žepkaitè, Vilniaus istorijos atkarpa $1939 \mathrm{~m}$. spalio 27 d.-1940 m. birželio 15 d, Vilnius 1990, s. 72-73.

28 J. Sawicki, op. cit., s. 70.

29 Lietuviu-lenku santykiu problema, „Naujoji Romuva” 1940, nr 18-19, s. 369-370.

30 M. Römerio 19391105 laiškas J. Petruliui.

31 M. Römerio 19400229 laiškas M. Urbšienei-Mašiotaitei, NMB RS, zesp. 14-613, karta 4.

32 V. Čečeta, Vilnius: 1939 metu ruduo, „Vakarinès naujienos” 1989, nr 249-250.

33 M. Römerio 19400229 laiškas M. Urbšienei-Mašiotaitei, karta 4. 
Z inicjatywy Römera i pod jego zwierzchnictwem 10 kwietnia w Wilnie założony został Klub Rotary ${ }^{34}$, do którego starał się ściągnąć bardziej oświeconych i tolerancyjnych inteligentów litewskich i polskich, aby poddawać dyskusji możliwości pokojowego wspólistnienia narodów zamieszkujących Wilno i inne aktualne dla Wileńszyzny zagadnienia ${ }^{35}$.

Römer zdecydowanie opowiadał się przeciwko przymusowej lituanizacji mieszkańców Wileńszczyzny, przeciwko pierwszeństwu dla obrony litewskich interesów etnicznych i przeciwko staraniom wzmocnienia ich pozycji. Uważał, że przeszkadzało to litewskim politykom w zrozumieniu specyfiki wielonarodowego terytorium i skutecznym rozwiązywaniu problemów jego integracji z państwem litewskim. Uważał, że politycy i społeczeństwo mylili się, kiedy zamiast rozwijać ideę obywatelskości, próbowali rozwiązywać problemy mieszkańców Wileńszczyzny na podstawie doświadczeń poprzednich 20 lat, kiedy to Litwa była pod względem narodowościowym homogeniczna. Jednocześnie też krytykował i odrzucał niekiedy podnoszoną próbę propagowania koncepcji państwowości wielonarodowej historycznie Litwy, co uważał za „donkichotowski romantyzm”: teraz perspektywę państwowości łączył z Litwą narodową, której stosunki społecznościowe będą zbudowane na podstawie idei obywatelskości i gdzie Litwini nie mieliby szczególnych praw, tylko pełniliby funkcje najaktywniejszego czynnika ${ }^{36}$.

I mimo że wieloletnie dążenia Römera do bliższych relacji Litwinów i Polaków nie przyniosły natychmiastowych efektów, to nie zniechęciło to do działań na rzecz wzajemnego zrozumienia i pogodzenia w przyszłości. A był to tylko początek wielkiego planu Römera. Niestety los na tym etapie przeznaczył na to ledwie niecałe półrocze.

\section{POCZĄTEK SOWIECKIEJ OKUPACJI}

W latach młodzieńczych Römer chętnie obcował z młodzieżą o poglądach prawicowych, brał udział w jej działalności, były mu bliskie idee społecznej sprawiedliwości, interesował się doktrynami propagującymi te idee ${ }^{37}$. Kierując się nimi w dojrzałym wieku i porównując je z rewolucyjnymi hasłami bolszewików z czasu Rewolucji Październikowej, uznawał rewolucję za istotny etap w dążeniu ludzkości do owej sprawiedliwości, a cele rewolucji uważał za poparte podstawami zachodniej cywilizacji i nawet chrześcijaństwa. Jego zdaniem na szczególną uwagę zasługiwała konstytucja ZSRR z 1936 r. — ,jeden z największych współczesnych fenome-

34 Rotary klubas Vilniuje, „Naujoji Romuva“ 1940, nr 16, s. 337.

35 M. Biržiška, op. cit., s. 552.

36 R. Miknys, Lietuvos valstybingumo koncepcijos istoriniai ir geopolitiniai aspektai. Teorija ir praktika, Mykolo Römerio mokslas apie valstybę, Vilnius 1997, s. 63, 70; idem, Mykolo Römerio požiüris ị Vilniaus problema, „Lituanistica” 4, 1994, nr 20, s. 30, 32.

37 M. Römer, Autobiografija, „Lietuvos mokslas” 1994, t. 2, księga 4 (5), s. 5. 
nów społecznych i jednocześnie jeden z najciekawszych i największych eksperymentów społecznych" ${ }^{38}$. I mimo że pozytywnie oceniane jej przepisy odróżniał od niemającej z nią nic wspólnego realizacji praktycznej, to jego wypowiedzi w badaniach sowietologicznych nie były sformułowane wystarczająco przystępnie ${ }^{39}$, co popchnęło niektórych do podejrzewania go o skłonności do poglądów bolszewickich.

Okupacja sowiecka zastała Römera w jego dworku w Bogdaniszkach (Bagdoniškis) w trakcie letniego urlopu. Trzeźwo oceniał swoją najbliższą przyszłość nie tylko jako człowieka „burżuazyjnej nauki”, lecz także „wroga klasowego” — ziemianina. Nie robił z tego jednak tragedii, a nawet próbował filozoficznie dodawać sobie otuchy:

Jestem człowiekiem społecznym i rozumiem, że nawet jeżeli osobiście stracę majątek [...] to nie zginie on, tylko [...] może trafniej i sprawiedliwiej przysłużyć się społeczeństwu, którego jestem członkiem, w którym żyję i działam i w którym żyje moja rodzina. Zasada społecznej solidarności, w którą wierzę, włącza mnie do społeczności mojej Ojczyzny, a co dobre dla społeczności, to nie może być złe dla mnie.

Pocieszał się, że z materialistycznego puntku widzenia jest czysty, bo nigdy nie miał innych pieniędzy prócz tych zarobionych własną pracą ${ }^{40}$.

Z drugiej strony martwiła go ta niejednoznaczność, w jakiej się znalazł, oraz wciąż niedostateczne zrozumienie własnej sytuacji w nowych realiach. Rozumiał, że nie może dołączyć do tych, którzy wspierali rzekomą rewolucję — „nie zrozumieją mnie jako ziemianina”; z drugiej strony zauważał, że na lokalny element „rewolucyjny" składali się głównie ludzie antyspołeczni, napędzani przede wszystkim chciwością, a czasem nawet rozpustą. „W Wilnie jestem profesorem, inteligentem pracy" - rozumował w te dramatyczne dni Römer, natomiast w Bogdaniszkach „W oczach lokalnej ludności jestem ziemianinem - społecznym wrogiem tych, którzy wprowadzają reformę ziemską”. Zatem „muszę żyć w zamknięciu w sobie, obcy dla jednych i drugich, niepasujący do świata rewolucyjnego ani kontrrewolucyjnego" 41 .

W Bogdaniszkach do Römera dotarła wiadomość od wieloletniego działacza politycznego E. Galvanauskasa, który przez krótki czas był członkiem tzw. rządu ludowego. Wzywał on Römera do szybkiego przyjazdu do Kowna celem wsparcia eksperckiego w spodziewanych negocjacjach z sowietami, które miały uchronić Litwę od inkorporacji do ZSRR. Nie zdążył zareagować na wezwanie: pierwszy skład rządu ludowego, nie pojmując jeszcze do końca narzuconej mu przez okupanta roli i naiwnie łudząc się, że utrzyma niepodległą Litwę ,,uwolnioną od smetonowców", został szybko uświadomiony o daremności wszelkich starań — sowieci nie zamierzali negocjować i poważnie oświadczyli, że decyzje co do

\footnotetext{
38 M. Römer, Sovietu naujoji 1936 metu konstitucija, Kaunas 1938, s. 42.

39 M. Römer, Valstybe ir jos konstitucine teise, cz. 1. Valstybe, t. 1, Kaunas 1934, s. 330.

${ }^{40}$ M. Römerio 19400707 laiškas V. Biržiškai, MAB RS, zesp. 163-521, karta 3.

41 Ibidem.
} 
dalszych stosunków między Litwą a ZSRR powierzą tylko „demokratycznie” wybranemu „ludowemu” sejmowi 42 .

Bacznie obserwując wzrokiem profesjonalisty dalsze wydarzenia polityczne na Litwie, Römer zauważał regularne rozminięcia się prosowieckich elit z elementarnymi wymogami demokracji: procedurę wyborów do tzw. sejmu ludowego uważał nie tyle za wybory, ile za plebiscyt na listę kandydatów, wyrażał zdziwienie wyborczymi plakatami w stylu ,nie dajmy ani jednego głosu wrogom ludu” w sytuacji, w której wyborca nie miał żadnego wyboru.

W trakcie życiowego zakrętu Römer starał się nie dawać oznak zagubienia. Można wręcz odnieść wrażenie, że nie rozumiał do końca charakteru zachodzących zmian ${ }^{43}$ albo głęboko ukrywał swoje prawdziwe zapatrywania na ówczesne wydarzenia. Z myślą o nadchodzącym roku akademickim, który, co dobrze rozumiał, siłą rzeczy musiał być inny niż zwykle, w liście do dziekana Wydziału Prawa obok zrozumiałego zaniepokojenia, rzeczowo sugerował już latem omówić zaistniałą sytuację i rozpocząć nowy rok akademicki przygotowanymi. Jego zdaniem kadra wydziału sama powinna wyjść z inicjatywą „wejścia w kontakt z politycznymi czynnikami administrowania oświaty"44.

Römer wyraźnie nie docenił wagi, jaką przykładała do reorganizacji oświaty i wychowania młodzieży według sowieckich szablonów ZSRR i nowa władza Litwy. Prawdopodobnie nie przewidział skali przyszłej reformy oświaty i oczywiście nie wiedział, że już 29 lipca władze nowego Ministerstwa Oświaty, sterowane z góry i niepotrzebujące oddolnych inicjatyw, wezwały rektorów Uniwersytetu Wileńskiego oraz Uniwersytetu im. Witolda Wielkiego i po prostu poinformowały ich o dalszym kierunku prac tych uczelni oraz zleciły im utworzenie takiego porządku, aby z początkiem nowego roku akademickiego obie placówki spełniały już stawiane przed nimi wymagania ${ }^{45}$.

Początek roku akademickiego upłynął pod znakiem chaosu wywołanego, formalną reorganizacją Wydziału Prawa. W celu uniknięcia demonstracyjnych masowych czystek wśród kadr Wydziału Prawa uważanego wtedy za podejrzanie polityczny, Ludowa Rada Komisarzy Litewskiej Socjalistycznej Republiki Radzieckiej ogłosiła zamknięcie wydziału z dniem 1 września, a całą kadrę odsunięto od pełnienia funkcji ${ }^{46}$. Z kolei inne postanowienie komisji ,pozwoliło na rozpoczęcie działania" od tego samego dnia nowemu Wydziałowi Nauk Prawnych. Personel nowo otwartego wydziału był w połowie zmieniony w stosunku do poprzedniego. Pozostał m.in. Römer ${ }^{47}$, któremu tak jak poprzednio powierzono funkcję

42 M. Römer, Dziennik, t. 37, karta 279.

43 J. Sawicki, op. cit., s. 70.

${ }_{44}$ M. Römerio 19400814 laiškas A. Janulaičiui, MAB RS, zesp. 267-792, karta 53.

45 Vilniaus universiteto istorija 1940-1979, Vilnius 1979, s. 10.

46 Vilniaus universiteto rektoriaus 19401015 aktas,/ VUB RS, zesp. 98-VU14, karta 49-50.

47 Vilniaus universiteto rektoriaus 19401016 aktas, / LCVA, zesp. R-856, opis 2, teczka 647, karta 96. 
profesora zwyczajnego i kierownika Katedry Prawa Państwowego ${ }^{48}$. Przyznano mu pedagogiczny tytuł profesora oraz naukowy stopień doktora nauk prawnych i wkrótce rozpoczęto wdrażanie na litewskich uczelniach sowieckiego systemu kwalifikacji kadr naukowych ${ }^{49}$.

W wypełnianym wtedy standardowym „Osobistym formularzu rejestracyjnym kadr” Römer zaznaczył, że jest Litwinem, rodziców określił jako szlachtę, wskazał brak powiązań z partiami czy innymi politycznymi organizacjami. W rubryce o aktywności rewolucyjnej wpisał, że w latach 1905-1906 brał udział w dziennikarskiej działalności o treści rewolucyjnej ${ }^{50}$.

Profesor starał się być lojalnym nowemu porządkowi prawnemu i sumiennie wykonywać powierzone funkcje na Uniwersytecie.

$\mathrm{W}$ pierwszym sowieckim semestrze, podobnie jak w latach poprzednich, Römer wykładał studentom prawnikom kurs prawa konstytucyjnego, nazwany teraz „Prawem konstytucyjnym Litewskiej SRR”, który obejmował rozwój konstytucyjny niepodległego państwa litewskiego od roku 1918 do sowieckiej konstytucji $\mathrm{z}$ roku $1940^{51}$, zatem treść kursu poświęcona była głównie aktom konstytucyjnym niepodległej Litwy.

Zadziwiające, ale pomimo niespokojnej atmosfery spowodowanej niepewnością jutra i wstrząsającego losu kolegi docenta, ostatniego ministra sprawiedliwości niepodległej Litwy A. Tamošaitisa (latem tego roku aresztowany przez NKWD, zginął w więzieniu), Römer lekko skrócił myśli swoich poprzednich wykładów, pozostając wiernym przepisowi, że nauka ,jest i musi być wolna, nieponiżana i nienaginana do celów spekulacji politycznych, serdeczna i odważna"52. Dalej doceniał konstytucyjny rozwój Litwy, co do zasady nie zbaczając z myśli przewodnich wykładów z czasów niepodległości ${ }^{53}$.

Römer zwrócił uwagę na to, że terytorium okręgu wileńskiego zwrócone Litwie na mocy umowy o wzajemnej pomocy z 1939 r. było znacznie mniejsze niż terytorium uznane przez bolszewików 12 lipca 1920 r. w umowie z Moskwą ${ }^{54}$, a oceniając wkroczenie Armii Czerwonej z początkiem II wojny światowej do Polski, nie próbował szukać słownego łagodniejszego odpowiednika dla zamiany terminu „okupacja”.

48 VU Teisès mokslu f-to branduolio 19400916 posèdžio protokolas, LCVA, zesp. R-856, opis 1, teczka 416, karta 29.

49 VU senato 19401201 posèdžio protokolas, LCVA, zesp. R-856, opis 1, teczka 33, karta 80; Švietimo liaudies komisaro 19401220 isakymas, LCVA, zesp. R-856, opis 1, teczka 40, karta 20-21.

50 M. Römerio „,Asmens lapelis kadrams registruoti”, LCVA, zesp. R-762, opis 2, teczka 494, karta $1-2$

51 M. Römer, Dziennik, t. 37, karta 334.

52 Universiteto rektoriaus prof. M. Römerio kalba 1937.II.16 d. Universiteto tarybos iškilmingajame posedyje, VD universiteto žinios 1937, nr 1-5, s. 7.

53 Lietuvos TSR valstybine teisé: Prof. M. Römerio 1940-1941 m. m. skaitytu paskaitu konspektai, cz. 1, red. A. Šidlauskas, neoficialus leidinys, Vilnius 1941; M. Römer, Lietuvos konstitucinès teisés paskaitos, cz. 1, Kaunas 1937.

${ }^{54}$ Lietuvos TSR valstybine teisé..., s. 9. 
Nie starając się owijać w bawełnę, tragiczne dla Litwy wydarzenia z 15 czerwca 1940 r. odbierał jako przewrót ${ }^{55}$. Zwrócił uwagę na „niezwykłe tempo” przeprowadzenia „wyborów” do tzw. sejmu ludowego, na przeniesienie inicjatywy wyborczej powierzonej ustawą samorządom lokalnym do organizacji kontrolowanych przez partię komunistyczną ${ }^{56}$. Według Römera „proradzieckie” czynniki, które umocniły się u władzy, próbowały formalnie obowiązującą konstytucję z 1938 r. ,interpretować zgodnie z nowymi warunkami” lub jej przepisy „rekonstruować na nowych konstytucyjnych precedensach" ${ }^{\circ 7}$.

Wprowadzony na Litwie reżim sowiecki był przez Römera określany jako „bezpośrednia socjalistyczna demokracja z prerogatywą kontrolną i zarządczą partii komunistycznej" ${ }^{8}$. Tłumaczył wprost, że Najwyższa Rada Litewskiej SRR, wbrew twierdzeniom sowieckiej konstytucji Litwy z 1940 r., nie może być uznawana za instytucję suwerennej władzy choćby $\mathrm{z}$ tego powodu, że jest ona ograniczana przez władze partii komunistycznej; w rzeczywistości jest tylko istytucją urzędniczą o charakterze pomocniczym ${ }^{59}$.

Römer krytycznie oceniał moskiewski, uznawany oficjalnie za obowiązkowo wzorcowy, program kursu sowieckiego prawa konstytucyjnego. Uważał go za nienaukowy, oparty tylko na podręczniku prawa konstytucyjnego przodownika sowieckich nauk prawnych A. Wyszyńskiego, odznaczający się jedynie frazesami z oficjalnych sowieckich tekstów, będący panegirykiem tej konstytucji i krytykujący wszystko, co niesowieckie ${ }^{60}$. Ignorując podobne imperatywy metodyki, kurs prowadził na swój sposób: semestr jesienny poświęcił ogólnym zagadnieniom prawa konstytucyjnego - pojęciu państwa, elementom i konstytucyjnym instytucjom - traktując to jako wstęp do sowieckiego prawa konstytucyjnego w kolejnym semestrze ${ }^{61}$, choć $\mathrm{i}$ wtedy najwięcej uwagi poświęcał formalnej analizie przepisów sowieckiej konstytucji.

Komunistyczna młodzież studencka, pomimo tego że wykładowca pozytywnie wypowiadał się o sowieckim ustroju, nieraz składała na niego skargi62. Tezy i myśli Römera wzbudzały niezadowolenie sowieckich funkcjonariuszy, co skutkowało „bezczelnymi pretensjami co do jego programu prawa państwowego i obiektywnego wykładania"63. Ponadto niezadowolenie władz uniwesytetu wzbudzało prowadzenie z własnej inicjatywy skróconego kursu sowieckiego pra-

${ }^{55}$ M. Römer, 1940/41 mokslo metu Lietuvos konstitucinès teisès programa [be v. ir m.], s. 4.

56 Ibidem.

57 Lietuvos TSR valstybinè teisé..., s. 10.

58 Ibidem, s. 21.

59 Ibidem, s. 16.

60 M. Römer, Dziennik, t. 37, karta 390; t. 38, karta 10.

61 M. Römer, Dziennik, t. 38, VUB RS, zesp. 75-14, karta 110.

62 M. Biržiška, op. cit., s. 556.

${ }^{63}$ Didžiai gerbiamieji fakulteto tarybos nariai. Rankraštis. Asmeninis J. Bulavo archyvas. Tekst prawdopodobnie sporządzony przez dziekana Wydziału Nauk Prawnych Uniwersytetu Wileńskiego doc. S. Žakevičiusa w styczniu 1943 r. 
wa konstytucyjnego w języku polskim dla studentów nieznających języka litewskiego oraz przeprowadzanie w tymże języku egzaminów ${ }^{64}$.

Będąc powszechnie uznanym specjalistą od prawa konstytucyjnego, Römer w swoim dzienniku przyznał, że dzień przed swoim pierwszym wykładem sowieckiego prawa konstytucyjnego czuł się niczym student przed egzaminem ${ }^{65}$. Także później, wykładając ten przedmiot, napotykał niezliczone problemy. Wciąż prześladował go strach przed błędami, przed naruszeniem dogmatu, uwierał go brak możliwości powiedzenia studentom, że sowiecka konstytucja nie ma nic wspólnego z życiem, gdyż po takiej deklaracji nie tylko oczekiwałby nieprzewidywalnych skutków, lecz także same studia straciłyby sens ${ }^{66}$. Niekończące się problemy stwarzały pytania studentów dotyczące np. deklarowanego prawa republik radzieckich do wystąpienia ze Związku ${ }^{67}$.

Pamiętnym dla społeczności uniwersytetu był akt obchodów 23. rocznicy Rewolucji Październikowej, w trakcie którego Römer na prośbę Senatu odczytał wykład wyraźnie niepasujący do sowieckich standardów stosowanych do publicznych wystąpień przy podobnych okazjach. Nic entuzjastycznego, agitacyjnego, żadnych pozdrowień i pochwał dla Stalina, partii komunstycznej, komunistycznego porządku, tylko wyczerpujące przemyślenia na temat rewolucji jako narzędzia osiągnięcia sprawiedliwego porządku społecznego, społecznej wolności, promowania nowego poglądu na pracę, a wszystko to abstrahując od rzeczywistości i polityki, bez wzmianki o sytuacji Litwy, bez demagogicznych deklaracji68.

Odczyt doczekał się niejednoznacznych ocen społeczności uniwersyteckiej i komunistycznych funkcjonariuszy. Wykład spodobał się profesorom i studentom, stał się dla nich przykładem, jak należy w obecnych, trudnych realiach wykładać bolesne zagadnienia, nie zdradzając sumienia naukowca ani lojalności wobec okrzepłego już porządku politycznego i społecznego ${ }^{69}$. Natomiast partyjni funkcjonariusze byli bardzo niezadowoleni i władze uniwersytetu musiały wysłuchać reprymend za rzekomo dwuznacze, a w rzeczywistości niespełniające obowiązujących sowieckich standardów myśli prelegenta ${ }^{70}$. Wykład ten miał też osobiste konsekwencje dla Römera: zasłużenie uznawany za jednego z najbardziej wybitnych naukowców-prawników Litwy, Römer był nominowany do członkostwa w nowo utworzonej Litewskiej Akademii Nauk, lecz funkcjonariusze partii komunistycznej, pamiętając jego wykład przed obchodami rocznicy Rewolucji, zablokowali jego kandydaturę ${ }^{71}$.

${ }^{64}$ M. Römer, Dziennik, t. 38, karta 43, 47.

65 M. Römer, Dziennik, t. 37, karta 331-332.

66 M. Römer, Dziennik, t. 38, karta 24-25, 27.

67 M. Römer, Dziennik, t. 37, karta 331; t. 38, karta 21, 24, 27.

68 Wykład wkrótce został opublikowany (M. Römer, Revoliucija ir laisvè, „Kultūra” 1941, $\mathrm{nr}$ 1, stając się ostatnią naukową publikacją profesora wydaną za jego życia.

69 M. Biržiška, op. cit., s. 556.

70 M. Biržiška, Vilniaus universitetas 1940-1941 m., Memmingen 1948, s. 38-39.

71 M. Biržiška, Prof. Mykolas..., s. 557; M. Römer, Dziennik, t. 38, karta 111. 
Odczuwszy sowieckie realia, Römer przyznał w dzienniku, że przed zetknięciem się z sowietami sympatyzował z nimi, cenił ich rewolucję, ale teraz jest przekonany, że to nie jest władza rewolucji czy mas, tylko dyktatura zorganizowanej kliki $^{72}$, której rzeczywistość nie ma nic wspólnego z pięknymi hasłami, wspaniałymi ideami, które tak idealistycznie wyglądały na papierze.

Dla władzy sowieckiej był obcy nie tylko dlatego, że wywodził się z ziemiaństwa, lecz był także „burżuazyjnym” działaczem państwowym, społecznym i naukowcem, który w swoich pracach konstatował ziejącą przepaść pomiędzy państwem sowieckim a ideałem sowieckiego państwa prawa. Pomimo sygnałów lojalności, początkowo tolerowany Römer zaczął być w wyższych sferach uważany za społecznie i politycznie niewiarygodnego. Istnieją dane świadczące o tym, że został wpisany na listy NKWD, ale poddać go represjom po prostu nie zdążono $^{73}$.

Ogólnie życie Römera nie rozpieszczało. W latach niepodległości był potrzebny i szanowany, a teraz wraz z innymi starszymi profesorami, którzy nie przejawiali specjalnej gorliwości, czuł się zepchnięty w cień. Jak nigdy dotąd czuł się samotny i zapomniany. Z rzadka zasiadając do pracy naukowej, Römer porównywał ją do trudu średniowiecznego mnicha-kronikarza ze względu na brak wyraźnych perspektyw do jej publikacji ${ }^{74}$.

Co smutniejsze, napotkał też trudności natury materialnej — utrzymanie rodziny w tym trudnym czasie pochłaniało cały jego skromny zarobek. Nic nie zostawało nawet na drobne wydatki osobiste. Pieniądze zdeponowane w banku zostały znacjonalizowane przez władzę sowiecką. Wysoki podatek od powierzchni mieszkalnej sprawiał, że utrzymanie stumetrowego mieszkania stało się wyjątkowo trudne, a starania o mniejsze lokum w budynkach uniwersytetu nie były skuteczne ${ }^{75}$.

Nie nastawiała też pozytywnie sytuacja w Bogdaniszkach, gdzie jego dwór został znacjonalizowany, choć udało mu się wystarać o prawo korzystania z 10 ha ziemi oraz budynków i sprzętów gospodarskich ${ }^{76}$. To niewielkie osiągnięcie lekko podniosło go na duchu, ponieważ dawało nadzieję nie tylko na utrzymanie więzi z rodzinnymi Bogdaniszkami, lecz co ważniejsze — pozwalało utrzymać źródło dochodu dla rodziny, gdyż sam nie uważał się za okaz zdrowia ${ }^{77}$.

72 J. Sawicki, op. cit., s. 71-72.

73 Ibidem, s. 72.

74 M. Römer, Dziennik, t. 38, karta 385.

75 Ibidem, karta 12, 14, 15, 53.

76 M. Römerio anketa, LCVA, zesp. R-856, opis 1, teczka 73, karta 13.

77 M. Römerio 19400814 laiškas A. Janulaičiui, MAB RS, zesp. 267-792, karta 53. 


\section{PODSUMOWANIE}

Rok 1940 w biografii Römera zajmuje szczególne miejsce ze względu na przeprowadzkę z Kowna - stałego miejsca pracy i życia — do Wilna wracającego na łono ojczyzny. Zeszło się to w czasie z końcem kadencji rektora Uniwesytetu im. Witolda Wielkiego oraz z ograniczeniem możliwości wykorzystania jego głębokiej wiedzy i niepodważalnego autorytetu przez pozostały w Kownie rząd do ważniejszych spraw państwowych.

Obok działalności uniwersyteckiej, dla kontynuowania której został przeniesiony, Römer poświęcał się wyjątkowo aktywnej działalności społecznej, którą wymogła aktualność problemu współistnienia Litwinów i Polaków. Jednak już po półroczu tryb i rytm życia został zmieniony przez sowiecką okupację: Römer jako społecznie obcy dla systemu sowieckiego i politycznie niepewny zamkną się w sobie, ale starał się pozostać lojalnym, sumiennie kontynuował obowiązki profesorskie na uniwersytecie zreorganizowanym na sowiecką modłę. Ze wszystkich sił starał się dalej przekazywać studentom obiektywny materiał naukowy.

\section{MYKOLAS ROMERIS IN VILNIUS IN THE 1940’S}

\section{Summary}

1940 year was very significant in the life of Römer, because he abandoned Kaunas for Vilnius. In the same time the great lawyer ended his activity as a rector of Vytautas Magnus University in Kaunas what, together with the effect of migration, limited in many areas the possibility of effective collaboration with Lithuanian government.

In ancient Gediminas capital Römer not only worked at the University, but also made many efforts for coexistence Poles and Lithuanians. But after six months, after the unification of Baltic Republics with USSR, the situation seriously changed. Römer as the "socially alienated" and "politically unsafe" was not a valuable person in the eyes of Soviet clerks, so he went to the "internal emigration", but constantly taught at the University as the lecturer of objective science. 